\title{
KEKAYAAN SUMBER DAYA LAUT INDONESIA "LOBSTER"
}

Jurnal : The Impact of Minister of Marine Affairs and Fisheries Regulation Number 12 of 2020 on the Sustainability of Lobster in Indonesia.

Negara yang memiliki banyak pulau yakni negara kita Indonesia. Indonesia dikenal dengan negara kepulauan dan tidak asing apabila Indonesia memiliki kekayaan dalam sumber daya lautnya, yang menarik para nelayan asal luar negeri untuk singgah dan mencicipi hasil sumber daya laut yang ada di Indonesia. Nelayan asal luar negeri singgah sembari membawa alat pancing yang bisa terbilang modern, agar bisa mendapatkan hasil yang besar. Namun sayangnya, nelayan dari dalam negeri masih saja berbelit dengan alat pancing yang bisa dibilang kurang men gikuti zaman. Kementrian kelautan dan perikanan akan merevisi beberapa regulasi dalam bidang perikanan karena memperlambat suatu usaha, serta menyiapkan alat memancing yang lebih ramah lingkungan. Menteri kelautan dan perikanan merevisi peraturan Nomor 12 Tahun 2020 tentang Pengelolaan Lobster dan Kepiting di Wilayah Negara Kesatuan Republik Indonesia, yang menimbulkan perdebatan yang sengit antara Menteri dan para Stakeholder. Kementrian juga merevisi peraturan tentang penyetujuan beberapa alat pancing yang sebelumnya telah dilarang. Di dalam Undang-Undang Dasar 1945 pasal 33 ayat 3 dan ayat 4 menyatakan apabila, benih lobster merupakan kekayaan sumber daya alam yang harus diproduksi dari pembenihan. Pemerintah diharuskan untuk mengelola lobster yang akan diekspor secara terbuka agar tidak menimbulkan permasalahan-permasalahan publik. Pemerintah bersikeras melaksanakan peraturan no 12 tahun 2020 yang berisikan tentang adanya bantuan untuk 13.000 nelayan yang kehilangan pekerjaannya akibat adanya peraturan yang sebelumnya.

Menteri berharap agar publik dapat melihat dua peraturan ini dengan utuh. Peraturan tentang pembangunan kelautan dan perikanan yang meliputi perlindungan dan pemberdayaan nelayan untuk peningkatan pendapatan para nelayan dan juga optimisasi atau penguatan perikanan budidaya untuk penyerapan lapangan kerja dan menyediakan sumber makanan yang mengandung protein hewani untuk konsumsi rakyat. Kebijakan pemerintah untuk membuka ekspor benih lobster dan melegalkan cantrang yang merupakan alat penangkap ikan memungkinkan adanya perselisihan antar nelayan. Sering sekali konflik-konflik yang terjadi antar nelayan yang mempermasalahkan alat penangkap ikan yang terbilang kurang ramah lingkungan. Konflik yang terjadi biasanya akibat perahu yang dibekali cantrang sesekali menabrak perahu nelayan kepiting yang mengakibatkan hilangnya jala kepiting yang sudah dipasang oleh nelayan, konflik-konflik terus terjadi tanpa ada penyelesaian. Cantrang bisa mengekstrak ikan yang kecil hingga besar tetapi cantrang merupakan alat penangkap ikan yang tidak ramah lingkungan. Masyarakat memiliki opini-opini yang tajam tentang pemerintah yang dianggap kurang memperhatikan nelayan kecil dan lebih mementingkan urusan investasi dan kurang terbuka dalam urusan ekspor benih lobster.

Apabila jumlah lobster yang ada di Indonesia ada banyak, maka harga lobster sendiri di Indonesia akan menjadi lebih murah. Harga lobster ditentukan oleh banyaknya jumlah permintaan dan penawaran yang ada, baik dari dalam negeri ataupun luar negeri. Meningkatnya permintaan dari pasar Internasional yang mengakibatkan terbitnya kebijakan baru yang bertujuan untuk 
meningkatkan kesejahteraan nelayan dan pembudidaya. Namun adanya kebijakan baru yang mengabaikan keberlangsungan hidup lobster yang ada di Indonesia. Beberapa pihak mengajak para stakeholder agar bisa melihat jauh kedepan dengan baik, karena sumber daya alam adalah suatu sumber untuk mendapatkan pendapatan dalam kegiatan produksi industry maupun jasa. Sering kali sumber daya laut yang di eksploitasi secara berlebihan, yang mengahalalkan berbagai cara agar mendapatkan hasil tangkapan besar dalam jumlah yang banyak tanpa melihat dampakdampak penggunaan alat penangkap yang tidak ramah lingkungan. Menurut roma di dalam "The Limits to Growth" (Meadow 1972) menjelaskan bahwa aka nada kegagalan di dalam dunia karena sumber daya alam yang jumlahnya semakin terbatas, namun tingkat konsumsi semakin meningkat. Banyaknya sumber daya alam yang sudah terdampak oleh polusi dan kerusakan yang diakibatkan oleh manusia, serta terbatasnya kapasitas lingkungan. Misalnya 11 wilayah di Indonesia memiliki sumber daya lobster dan mengelolanya di zona merah ataupun zona kuning. Yang artinya pengelola tersebut tidak bisa meningkatkan panen lobster dewasa dan menangkap benih lobster secara lebih hati-hati. Memang sulit untuk memberi batasan antara sumber daya yang tidak dapat diperbaharui karena jumlahnya yang terbatas, dan sumber daya yang dapat diperbaharui karena jumlahnya yang tidak terbatas.

\section{Putu Setyarini 130118902}

